\title{
An integrated model for public service media governance based on participatory governance and actor-centered institutionalism: Initial application to the independence of the Polish public broadcaster TVP S.A.*
}

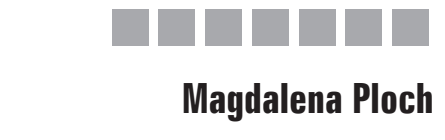

WWU UNIVERSITY OF MUNSTER, GERMANY

DOI: 10.19195/1899-5101.10.2(19).3

\begin{abstract}
The aim of the article is to introduce a governance analysis model which can be used for the investigation of public service media (PSM) change processes. With its help it is possible to explore to what extent the PSM system is dependent on political as well as economic influences in a timeline. The PSM governance model derives from the theoretical framework of the actor-centered institutionalism (ACI) and the participatory media governance approach. Participatory media governance allows civil society members to be included in the investigation. With the help of ACI and the agent-structure dynamics model one can analyze three different spheres of actor's actions which can be observed empirically: sub-systemic orientation horizons, institutional arrangements and the actor's constellations. Based on these preliminary considerations, the model is applied to PSM governance in Poland since the socio-political transition of 1989 until 2016.
\end{abstract}

KEYWORDS: participatory media governance, actor-centered institutionalism, public service media (PSM), civil society, transformation, Telewizja Polska S.A.

\section{INTRODUCTION}

The transformation of a media system, broadcasting in particular, is considered to be successful when it independently follows its own logical function. A democratic model of mass communication is ideally based on two structural principles: diversity and freedom (Article 11, Paragraph 2 of the Charter of Fundamental Rights of the EU; Dahl, 1989, p. 220; McQuail, 1992, p. 29). Whereby "the characteristic freedom depends mainly on structures ensuring the political independence of the media"

* The paper presented here provided in a similar form a contribution to the RIPE conference in Antwerp and Brussels, Belgium on September 22-24, 2016. 
(Voltmer, 2000, p. 126). In February 2012, in their Declaration on public service media (PSM) and the related recommendation, the Committee of Ministers of the Council of Europe defined the primary mission of PSM and declared: "public service media must remain independent from political or economic interference and achieve high editorial standards of impartiality, objectivity and fairness". ${ }^{1}$ Based on this Declaration, in 2015 the European Broadcasting Union (EBU) also outlined the fundamental principles for PSM governance in its "Legal Focus". In addition to secure and appropriate funding, the EBU Core Values of public service media include independence, accountability, transparency and sustainability (Wagner \& Berg, 2015). In particular, the analysis of the project presented here concentrates on the above-mentioned core requirement which postulates that PSM must remain independent of political or economic interference.

Unfortunately a lot of public service media in Europe wrestle with a lack of funding and increasing commercialization. Furthermore, in the former communist-ruled states, an over-politicization can be often observed. For example, at the beginning of January 2016 the new Polish government introduced so-called small media legislation which allows the Minister of State Treasury to directly appoint and dismiss all members of the supervisory and management boards of TVP and PR (Polish Radio) without the approval or consultation of the broadcasting authority and constitutional institution - The National Broadcasting Council (Krajowa Rada Radiofonii i Telewizji, KRRiT) and without any public debate of all relevant stakeholders. ${ }^{2}$ In February 2016, delegates from the European Federation of Journalists (EFJ), the European Centre for Press and Media Freedom (ECPMF) and the International Press Institute (IPI) assessed the current situation of PSM in Poland. The group interviewed journalists, lawyers, and civil society activists, including representatives of Poland's leading journalist associations. The delegation made recommendations relating to the development of standards concerning ethics, independence from government interference and press freedom, and concluded: "We recognize that Poland's public broadcaster has for many years been seen as a political pawn and a prize for the governing party". ${ }^{3}$

To assess how this current critical situation within Polish PSM governance arose, an analysis model is used. Reflections on governance models in the area of interest are still required, and the Council of Europe "is interested in examining the matter because it is a crucial matter for the future of PSM" (Council of Europe, 2009, p. 3). Thus, the main aim of this article is to introduce a PSM governance model which is based on the theoretical considerations of the actor-centered institutionalism (ACI), the agent-structure

${ }^{1}$ Council of Europe Recommendation CM/Rec(2012)1 of the Committee of Ministers to Member States on public service media governance. Retrieved February 15 and August 26, 2016 from https:// wcd.coe.int/ViewDoc.jsp?id=1908265 and Declaration of the Committee of Ministers on public service media governance https://wcd.coe.int/ViewDoc.jsp?id=1908241.

2 This legal amendment is the first step in a forthcoming major media reform in Poland, which is to replace the 1992 Broadcasting Act.

${ }^{3}$ EFJ-ECPMF-IPI urge the Polish government to guarantee public broadcasting independence. Retrieved February, 1 and August, 30, 2016 from http://europeanjournalists.org/blog/2016/02/01/effecpmf-ipi-urge-the-polish-government-to-guarantee-public-broadcasting-independence/. 
dynamics model of the well-known German sociologist Schimank (2007, p. 223), and the participatory media governance approach. The model presents media regulation in the form of a triangle of political, economic and public objectives, in which is the assumption from a normative perspective that public service media maintains egual relations with all relevant environments. Excessively close ties between PSM and one of these environments would affect its performance. A central proposal against the politicization of PSM and their strengthening presented here is the consistent involvement in broadcasting regulation of socially relevant actors. Consequently, this project will not only examine the disproportionate politicization and the excessive intervention of the media industry in the internal PSM business, but it will also analyze a further influencing factor of socially relevant stakeholders. Many scientists from various socio-political areas complain about the current national regulatory crisis and demand a stronger and deeper democracy (Barber, 2004; Crouch, 2008; Fung \& Wright, 2001; Norris, 2012). Parallel to these general demands, scientists and practitioners in the media field (Carpentier, 2011, 2016; Dahlgren, 2003) as well as within PSM governance in particular, claim to be able to counteract this regulatory crisis by involving civil society in the regulatory process (Jakubowicz, 2008; Lowe, 2010; Syvertsen, 2004). This sentiment is echoed in the EBU Legal Focus, which states that "the risk of over-politicization may indeed be lower in alternative systems where a majority or large parts of the membership are nominated by various groups of society" (Wagner \& Berg, 2015, p. 14).

\section{PARTICIPATORY PSM GOVERNANCE}

When it comes to analyzing media policy and regulation, researchers can no longer avoid the concept of governance. Originally, the term comes from the field of institutional economics and has enjoyed uninterrupted popularity for about 20 years in many different debates and in different disciplines (Grote \& Gbikpi, 2002; Kooiman, 2003; Mayntz, 2004; Rhodes, 1996). Unfortunately, the term therefore does not always have the same meaning, preventing any standard textbook definition. The situation is similar for the term participation, which will here be combined with the term governance. Here, too, different definitions are used by researchers and practitioners. Initially, it is therefore necessary to define the way in which participatory governance is used.

The general characteristics of governance phenomena include the observation that the laws and regulations made by the state represent only one possible form of political regulation of social relationships. Increasingly, in addition to classical hierarchical state regulation, very complex structures appear in the form of economic networks, as non-governmental organizations are involved in policy-and decisionmaking processes at the level of nation states themselves, as well as at the EU level or even at a global level. In this respect, many scholars of various disciplines declare that the state as the center is no longer in a position to regulate the complex structures, which have various networks of private and civil society actors (Bevir, 2011; Kooiman, 2003; Mayntz, 2009). Furthermore, others have stated that the pure hierarchical form 
of government (governance by government) is declining, and even that the state is disintegrating (Beisheim \& Schuppert, 2007).

Thus there emerges a common core of the governance approach which can be characterized by the following broadly defined definition, whereby the state is not replaced by the new players on the scene, but instead has a managerial function (although it is only one actor among many). Governance is accordingly described as: "the totality of existing forms of intentional collective regulation of societal matters in a state" (Mayntz, 2004), or, alternatively, in an analytical perspective as "collective actions and decisions in complex institutional structures (...) to cope with interdependencies" (Benz \& Dose, 2010, p. 253). Investigations based on the concept of governance usually focus on the link between policy-making and the media industries, thus primarily focusing on political and economic actors.

Participatory governance, as the horizontal extension of governance (Puppis, 2007), an extension from political stakeholders to private/civil actors, has so far only been given sporadic attention by debates on governance (Walk, 2011, p. 131). The importance of civil society involvement for media governance can be explained through special characteristics which are attributed to civil society. "Through its acute sensitivity to problems, capability for discourse and orientation to the common good, it can be seen as a particularly qualified actor where the central infrastructure of democratic societies is involved" (Eilders, 2011, p. 176).

Through the participatory variant of governance, other governance strands which are "based more around empowering the people as consumers, rather than as democratic citizens" have been criticized (McLaverty, 2011). The democratic theory underpins the participatory governance approach, as it is based on the idea that a functioning democracy requires active citizen involvement (Barber, 2004; Geissel, 2012; Pateman, 1970). Thus, participatory governance is related to one of the classical strands of democratic theory: the participatory theory of democracy, which has the longest tradition. This emphasizes the strong role of the antique "demos", which refers to people who decide directly themselves about issues which affect them. Furthermore, can Rousseau's political philosophy be noted with the famous claim: "All State power emanates from the people" which is considered as a fundamental democratic principle.

The participatory theory experienced several revivals, where representative democracy was denounced as being deficient, and the call for stronger involvement of the people themselves in the formation of political will and the decision-making processes became louder. In this spirit, Almond and Verba with their "civic culture" study proclaimed the start of the participatory revolution in 1963. Here the concept of participation stands in direct relation to the concept of civil society. The willingness for political participation is a basic requirement of civil society, whereby civil society is understood to be "a political sphere whose actors address their wishes for selfdetermination and democratization to the political institutions" and "not to restrict policy-making to state actors" (Klein \& Rohde, 2003, pp. 1-2). The reformist civic movements of the "Velvet Revolution" of the 1980's in Eastern Europe were based on 
the concept of civil society (Arato, 1981; Jakubowicz, 1996; Michnik, 1985; Smolar, 1996). Finally, since the 1992 Rio summit on Environment and Development, some fifty thousand activists participated in summit proceedings, whereby civil society discourse experienced a new revival in both scientific and political discussion.

Similarly, media scientists claim that "media governance has been one of the most influential notions in the field of media and communication policy in recent years" (Karppinen \& Moe, 2013). Moreover, although communication science recognizes the civil society and participatory potential (Carpentier, 2016; Dahlgren, 2003) there has hardly been any theoretical integration of the participatory strand in the media governance concept. Firstly, this may be due to the fact that democratic theory questions are assigned to the "inherently normative approach" (Puppis, 2010b, p. 136) of governance, so-called good governance which was firstly put forward by the World Bank in the 1980's. Secondly, several authors deny civil society, as the only audience, its active actor status (Puppis, 2010a, p. 203). In this way, participation is not taken into account, especially in the analytical approaches.

The situation is different in the areas of PSM governance, where leading names have, for years, been trying to reflect the relationship between PSM and its public (Jakubowicz, 2008; Lowe, 2010). With the dissolution of the monopoly for public service broadcasting (PSB) came an interest in definitions and definition typologies for this relationship. Above all, the Scandinavian media scientists Syvertsen and Søndergaard stood out with their idea of defining the PSB as "the relationship to society" and as "broadcasting in the service of the audience" (Søndergaard, 1999; Syvertsen, 1999).

As early as 2009 the Media and Information Society Division Council of Europe used a broader definition of governance and cited the UN Economic and Societal Commission for Asia and the Pacific (ESCAP): "an analysis of governance focuses on the formal and informal actors involved in decision-making and implementing the decisions made and the formal and informal structures". In addition, the Council of Europe spoke of "the democratic participation of the public" and looked for possible new future governance models on the grounds that "in order to survive and maintain their crucial role in modern societies, PSM have no other solution than to get closer to the public" (Council of Europe, 2009). With reference to PSM governance the EBU also mentioned in the Legal Focus: "A modern approach to governance also covers the way the legal framework is implemented in practice, how the actors behave within the framework and the relationship with external stakeholders: audiences, public authorities, economic players and civil society" (EBU, 2015). In addition, the EBU initiated measures through its project VISION2020 for producing a set of indicators and a mythology to assess and report on PSM's contribution to society (EBU, 2014).

However, the increasing participation of non-governmental and non-democratically legitimized actors involved in setting and enforcing binding rules has met with criticism from a considerable number of scholars. Thus, Benz and Papadopoulos ask: "To what extent are the new patterns of network and multi-level governance compatible with democratic standards?" (Benz \& Papadopoulos, 2006, preface). Offe (2009, 
p. 556) argues similarly: "Such an arrangement for the nation-state would, however, have to do without any evident connection to democratic legislation as the source of 'binding decisions', nor would it allow for the legal regulation and review of procedures and outcomes. It much more resembles the political-institutional formation that Colin Crouch has described as 'post-democracy' under which economic actors enjoy the license to do as they please". Others point beyond the problem of a lack of legitimacy to problems of selectivity of innovative forms of governance: "Efficient regulation is not synonymous with democratic accountability" (Newman, 2000). Finally the Polish sociologist Załęski (2012, p. 251) goes so far as to say: "Civil society is a neoliberal ideology legitimizing an attack of economic elites on institutions of the welfare state through development of the third sector as its substitute". Exactly both of the main criticisms outlined above, selectivity and lack of legitimation of civil society actors are taken into consideration when analyzing each of their respective impacts on PSM governance. This takes place among others with the aid of the actor-centered institutionalism approach.

\section{PSM PARTICIPATORY GOVERNANCE LINKED TO ACTOR-CENTERED INSTITUTIONALISM (ACI)}

To examine the degree of influence the various social actors from the fields of politics, economics and civil society have on PSM governance, a theoretical framework based on the participatory governance perspective combined with actor-centered institutionalism (ACI) is utilized. The governance perspective itself does not offer analytical instruments for the research of theoretical governance issues, but it is known for its high compatibility with other theories. "If communication scholars are able to look beyond governance as a label for new forms of regulation and to embrace it as an analytical concept, they can truly benefit from this integrated and theoretically open view on rules" according to Manuel Puppis (2010b, p. 145). Similarly, Patrick Donges (2007) tries to link the media governance approach with new sociological institutionalism (NSI). Both authors explain their decision for NSI to the characteristic of "rules", which, for example, affect "the connection between media organizations and the state or political actors, or the perception about which regulatory decisions are legitimate and which are not" (Donges, 2007, p. 328). Both of them also refer to Scott's work by defining institutions as: "symbolic and behavioral systems containing representational, constitutive and normative rules together with regulatory mechanisms that define a common meaning system and give rise to distinctive actors and action routines" (Scott, 2001, p. 48).

The actor-centered institutionalism presented below is also suitable for linking with the analytical concept of governance. This approach, similar to governance, is "closely connected with an institutional way of thinking"4 (Puppis, 2010b, p. 143).

${ }^{4}$ In her governance and steering approach comparison, Mayntz (2004) emphasized that governance approach deals with regulatory structures and is institutionalized, while the political steering approach is actor-centered. 
However, the role of the relevant actors is not marginalized. In particular, when investigating the society's base in all its facets, the analysis of the relevant stakeholders with a micro perspective is indispensable. In addition, an important analytical strand of civil society research advocates an actor-centered perspective (Zimmer, 2012).

The ACI was developed at the end of the 1980's by Scharpf and Mayntz at the Max Planck Institute of Social Research (the so-called Cologne School of Governance) in response to the internationally held theoretical debate on institutions, the so-called "Renaissance of Institutionalism" (Luthard, 1999, p. 160). Against the background of progressive processes of social differentiation, the aim was to overcome the classical doctrine of the separation of state and society. This stated that only the state, as the political control center, is accorded steering capability and all other social associations and organizations are merely objects to be steered. There then began a new understanding of politics and society, whereby this approach can be regarded as the precursor of the current governance debate. "Society no longer appears to be a basically or tendentially 'unpolitical' institution, but a political form which has significant independent potential to deal with particular circumstances and parts thereof" (Luthard, 1999, p. 160). The term steering was replaced by concepts such as "new stateliness" or "new forms of government". In the words of Mayntz: "Formulations to which the eggshells of the traditional (continental European) concept of state still clearly adhere" (Mayntz, 2004).

Based on the ACI, the German social scientist Schimank (also a former scientist in Cologne) developed an agent structure dynamics model. It connects the actoraction perspective to the systems-structure perspective. By "the acting interaction" of actors, three societally observable dimensions of patterns are composed: the sub-systemic orientation horizons, the institutional arrangements and the actors'

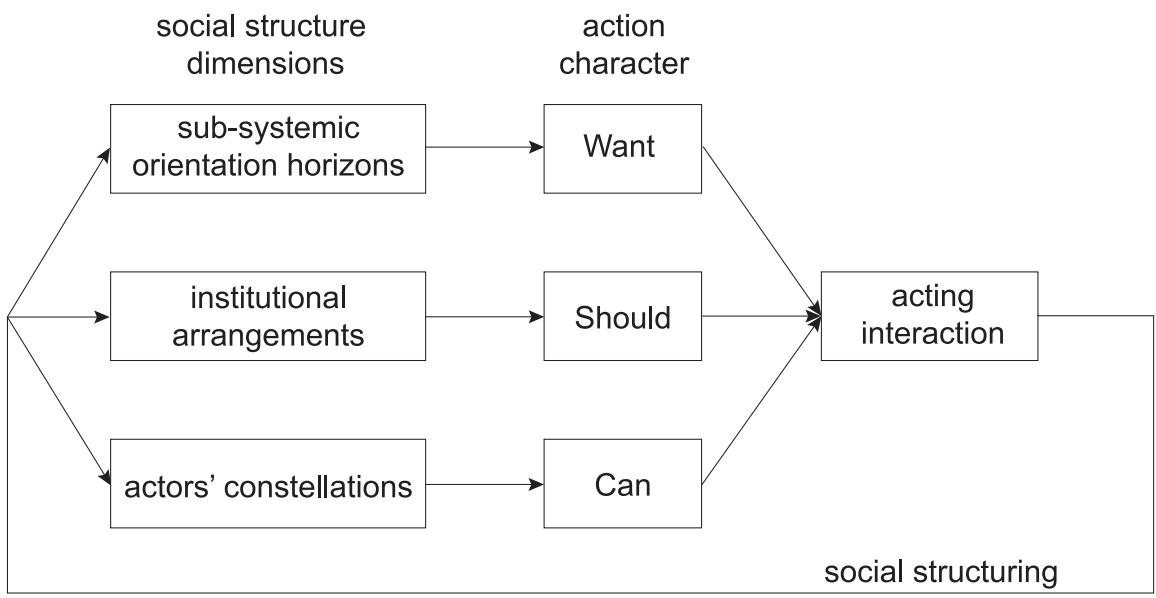

Figure 1. Agent Structure Dynamics Model

Source: Schimank (2007, p. 223). 
constellations. With the help of this model, complex relationships of political, economic as well as civil society power structures can be analyzed. It is open to the action theories, and in the center of its approach stand the actors. In addition, with the aid of ACI, it is possible to present the numerous interdependencies of PSM to other social sub-systems, which is shown in the model below.

\section{PSM GOVERNANCE ANALYSIS MODEL}

For the study of the steering crisis, which has been evident within the Western as well within the Eastern European PSM governance, a model has been used that integrates public service media into the network of the neighboring social systems: politics, the economy, and society. A group of media scientists from the University of Zurich introduced the initial model together with the Hans Bredow Institute at the University of Hamburg (Jarren \& Donges, 2005, p. 183; Jarren et al., 2001, p. 62). This model was based on the concept of the relationship with society, which was primarily put forward by the Scandinavian media scientists Syvertsen (1999) and Søndergaard (1999). At the same time, similar considerations came from Hamelink and Nordenstreng, who "borrowed" their triangle model from the social scientist Galtung (1999) did not relate it explicitly to PSM but to media in general (Hamelink \& Nordenstreng, 2007, p. 226). The model helps integrate the relevant social groups into the regulation of public service media. Consequently, if no new actors are institutionalized "to represent the public's interest (...), the latter will only enter indirectly into the broadcasting system. Consequences of inadequate or unbalanced links between the Public Service and society are either an alienation or a disproportionate influence of particular social groups" (Puppis, 2010a, pp. 203-204).

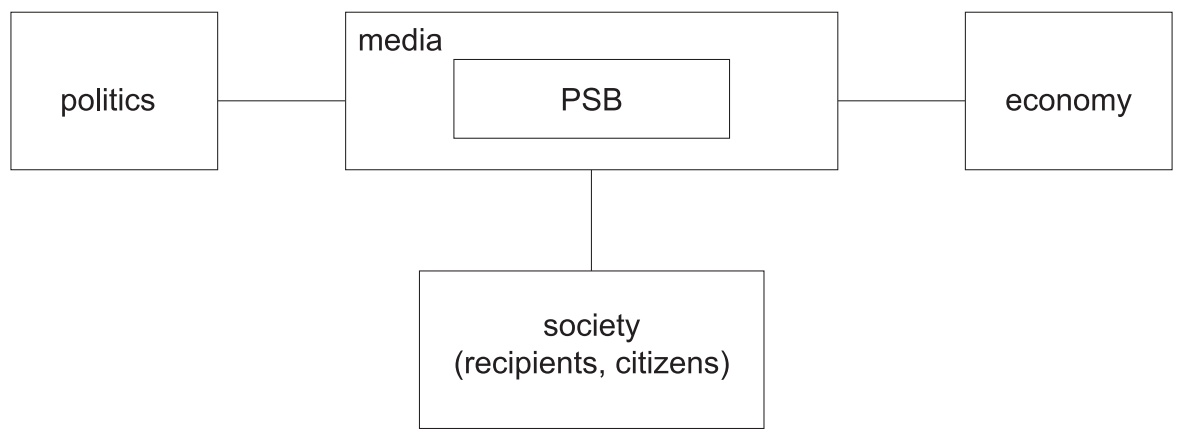

Figure 2. Public service media as a relationship network

Source: Jarren and Donges (2005, p. 183).

There is the normative specification, in which the equilibrium of forces of three factors is indispensable for the effectiveness and legitimacy of PSM. It is important from a normative perspective that public service media maintains equal relations 
to all relevant environments, because excessively close ties between PSM and one of these environments would affect its performance.

With this basic idea of placing PSM in the relationship network, the considerations regarding its independence are inseparably linked. Many scientists have already examined the question of media independence (Karppinen \& Moe, 2016; Klimkiewicz, 2015; Wagner \& Berg, 2015). Ultimately, a general definition is as follows: "independence refers to an absence of external control. Here independence means freedom from the influence of others, but also describes the capacity of an individual or institution to make decisions and act according to its own logic" (Karppinen \& Moe, 2016, p. 106). In the essay "Secure autonomy, increase openness - securing the Public Service" Donges similarly distinguishes between negatively and the positively defined freedom. While negative freedom means the independence of public broadcasting from state actors or interventions of the economy, in the case of positive freedom, the autonomy of the broadcasting action system is emphasized (Donges, 2003).

If one imposes the basic theoretical ideas of Schimank's agent structure dynamics model onto the PSM relationship network, this explains the complex actions of actors both in one and several social systems. The ACI perspective allows one to speak of a functional broadcasting sub-system or a PSM system which is understood to be "a society-wide institutionalized, function-specific action context, which is characterized by a special sense" (Mayntz, 1988, pp. 17-18). For PSM, this sense could be understood as the remit or public value. Patrick Donges transfers the agent structure dynamics model to broadcasting. This results in a model that takes into account the network relationship of broadcasting as a functional sub-system to its environments, politics, the economy, and society and which can be utilized as an analytical model for media governance research. However, Donges does not regard the society component as sufficiently institutionalized and maintains that society is not a player which is component to act (Donges, 2002, p. 123). Here, the basic ideas of participatory governance come into play.

Donges describes broadcasting as a sub-system of system journalism. PSM is not regarded as an independent system, but merely as a specific orientation of the broadcasting system. In contrast, the analysis presented here examines PSM as a sub-system of the broadcasting system. The general sense of the broadcasting system is journalism (Donges, 2002, p. 113), where for PSM the sense can be defined as the PSM remit and public value. Because the sub-systems' limits in terms of actor-theoretical differentiation are permeable, it follows that the action orientations of adjacent sub-systems coexist in a subsystem. Accordingly, for the PSM sub-system, it can be assumed that the orientations of politics, the economy and society cross over the systemic limits of PSM. The question to be empirically answered here is what proportion of the "foreign" orientation horizons exists at the level of PSM actors.

On the one hand, preserving autonomy in this context means that one's own sub-systemic sense must not be overshadowed by the action orientations of other systems or, in relation to broadcasting, "that journalism gains dominance over other 
action orientations through the process of functional differentiation, but not that these are completely eliminated" (Donges, 2002, p. 115). On the other hand, broadcasting would not be "autonomous" if it asserted its journalist action orientation $100 \%$ and reduced other system logics to nothing. Rather, it would be a case of one's own orientation, journalism, gaining dominance over other action orientations by means of a process of functional differentiation. Autonomy would therefore mean

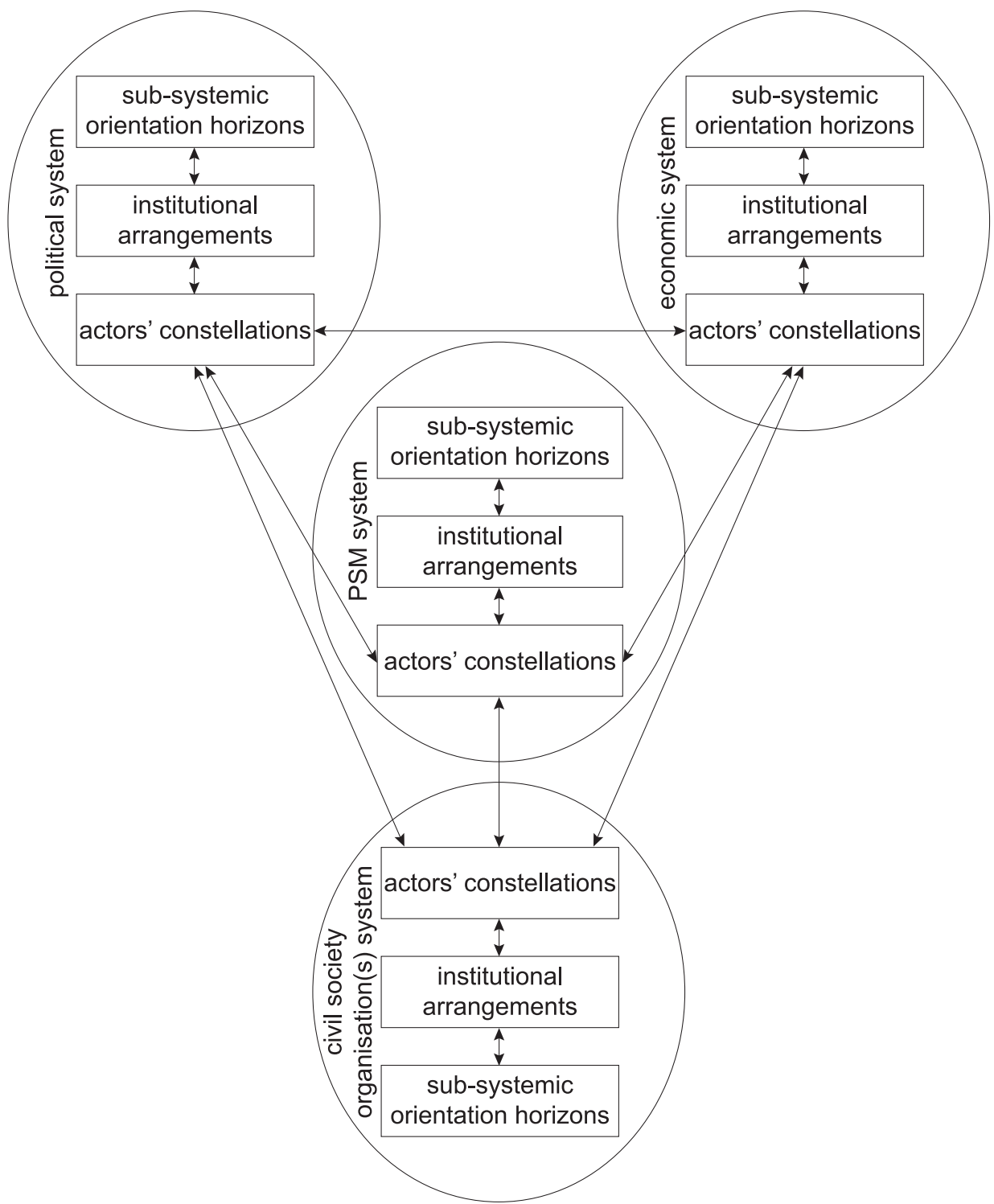

Figure 3. PSM Governance Analysis Model

Source: Adapted from Schimank (2007, p. 223) and Donges (2002, p. 130). 
"a hypothetical endpoint of the process of functional differentiation" (Donges, 2002, p. 115). Bennett (2014, p. 2) comments similarly on the great importance of the issue media independence, which "functions as a utopian vision of the media's role in society for those who regulate it, own it, work within it and even study it". Finally, the PSM governance analysis model, which is shown in Figure 3, emerged.

\section{POTENTIAL APPLICATION AND POSSIBLE RESEARCH FINDINGS}

In order to analyze PSM's political and economic dependence, this chapter will use the governance of the Polish public service broadcaster Telewizja Polska S.A. (TVP S.A.) as a case study. As a state corporation, TVP is the only public provider in Poland. Since it was founded in 1989, it has been regarded as "the regional leader" within the Central and Eastern European region, according to its distribution (more than 90\%) and the TV broadcasting market. ${ }^{5}$ Its information and news programs are the most popular and are the main source of information acquired through television. ${ }^{6}$

Nevertheless, since the beginning of its establishment in 1989, or officially in 1992, PSM in Poland has been treated as a political catch or extended arm of the party which could unite the most votes in Parliament. Political (state) influence was reflected in the protracted negotiation of broadcasting laws - also called media war - in the assignment of positions in the regulatory authority KRRiT and in the supervisory as well as management boards of public radio and television based on political calculations (political parallelism). Thus the current strong state dependence is a result of the former Polish governments' failure to establish an independent public service media which would be free of disproportionately strong influence by political parties (Głowacki \& Urbaniak, 2011; Jakubowicz, 2013; Stępka, 2010) and would be securely financed. ${ }^{7}$ Bajomi-Lázár describes PSM governance in Poland as a complex affair: "The political system in post-communist Poland has been described as one dominated by a 'culture based on clientelism and personalized relations', including 'the idea of colonizing posts in the public media, to the extent that the 'nomenklatura of a single Communist Party was replaced by a multi-party nomenklatura”' (Bajomi-Lázár, 2015, p. 74) and "the state (...) has become a hostage of various groups and interest trying to dominate its institutions” (Bajomi-Lázár, 2015, p. 75).

5 The results of the measurement of the audience market can be seen in the information from Nielsen Audience Measurement. Retrieved August 26, 2016, from: http://www.agbnielsen.pl/2016-0731,2183.html.

${ }^{6}$ According to recent polls, TVP's information programs: "Wiadomości" and "Teleexpress" are watched by 24\% of the population. Retrieved August 17 and 26, 2016 from http://www.wirtualnemedia.pl/artykul/wiadomosci-teleexpress-i-fakty-to-glowne-zrodla-informacyjne-polakow.

7 Retrieved December 11, 2009 and August 30, 2016, from http://www.edn.dk/en/news/news-story/browse/31/article/ebu-calls-for-stable-funding-for-polish-public-service-media/?tx_ttnews\%5BbackPid\%5D=139\&cHash=47fd8eb1de7119afla7e3a846bf07631. 
To analyze the forces influencing Polish PSM governance, the above introduced network model has been applied. The three constituent elements of PSM as sub-system of broadcasting are: sub-systemic orientation horizons, the institutional arrangements and the actors' constellations. All three elements act together in empirically observable action, so that this creates study categories. Furthermore, relationships to neighboring social systems exist, which exert considerable influence on PSM governance. Based on the model, this study examines the question whether the political and the economic impact on the PSM have changed within the study period (1989-2016). Moreover, the study intends to determine how large are the influences of TVP regulators themselves and alternative forms of governance. Special attention is paid to the opposing forces and groups of intellectuals in the arts and sciences; these groups are repeatedly being set up in the country of the trade union "Solidarity". For instance, Hess (2015, pp. 226-227) sees the development of think tanks in Poland as a response to the democratization of society: "They are the manifestation of a reaction to the ongoing tendency of change in the sphere of public life and democracy". Accordingly, this chapter will examine the actual or intended influence of think tanks, foundations, associations, trade unions, and civil movements on the PSM governance of Telewizja Polska S.A. However, this study does not blindly follow the thesis that claims the involvement of civil society groups in the regulation process would alone eliminate the strong influence of political and economic systems on the PSM. Rather, there will be critical examination of the sphere of influence of these actors and an analysis of the interests behind these organizations.

The investigation of the respective systemic orientation horizons, the institutional arrangements and the actors' constellations is designed as a classical stakeholder analysis. This involves conducting qualitative, partially structured interviews with four different social groups of stakeholders (TVP directors, politicians, economic and civil society representatives). In the first half of 2016, key experts were questioned. Among them were the chairman and members of the National Broadcasting Council (KRRiT), TVP directors, and representatives of the Committee for Public Media, as well as the chairman of the Association of Journalists (SDP Warsaw) and the chairperson of the Trade Union Confederation Wizja. The stakeholders were asked about their opinions regarding TVP governance and their own perceptions, expectations, and ideas as well as their internal and external constellations.

Finally, it can be stated, in a first analysis step, that an equally important factor which affects the autonomy of Telewizja Polska are aspects of politicization and commercialization. The role of civil society organizations and movements has been unable to prevail against the strong political and economic influences (Głowacki, 2015, pp. 31-33). Although numerous committees and social movements arose over the course of time aimed at improving PSM governance and several foundations initiated public debates, there was no change to the status-quo. The most wellknown grouping to date, and one which is still active, is the Citizens Committee for Public Media (Komitet Obywatelski Mediów Publicznych), founded in 2009, which 
is a prime example for the analysis of participatory media governance. The activists initiated a Draft Act on Public Service Media, which a) was aimed at permanently removing public media from political control and b) demanded a guarantee of long-term public financing. ${ }^{8}$ The implementation of these ideals failed, just like the other committed projects in previous years did, as a result of resistance by political representatives (Borowik, 2011).

\section{CONCLUSIONS}

To examine the degree of influence the various social actors from the fields of politics, economics and civil society have on PSM governance, the above introduced network model has been applied. The model was developed from the perspective of participatory governance and actor-centered institutionalism. Media governance studies usually look at the link between policy-making and the media industries. However, PSM governance research in particular emphasizes the importance of PSM's contribution to society as a crucial element. For this reason, this project is also keenly interested in a third group of actors, namely civil society stakeholders. The concept as a framework for the analysis of often complex governance phenomena within PSM is useful as its theoretical and analytical potential includes unauthorized players with equal rights in the PSM governance analysis. In addition to the regular actors included in such analyses, such as political parties, producers, representatives of social organizations and social movements can also be a part of the analysis. These actors and their mostly informal relationships are, in fact, hardly ever included in investigations of PSM governance.

Furthermore, the participatory governance perspective combined with the actor-centered institutionalism approach allows the role and behavior of the actors to be a special focus of this analysis. So, the linking of the media governance approach recommended here is in contrast to the linking of media governance with new sociological institutionalism and the regulatory structure which plays a central role there. The ACI approach allows the investigation of complex governance matters which occur over long periods of time. As a result of the actor-centered analysis, one obtains many different points on the timeline which indicate the degree of differentiation of the functional PSM sub-system, i.e., social influences (political, economic, and public). As there is a theoretical differentiation perspective behind the ACI approach, similar to that behind the pure systems theory, various grades of differentiation can be defined with this approach, i.e., the degree of dependency on other systems and the status of its own systemic autonomy.

In addition to the innovative view of civil society as a partner in relation to media governance, there is a critical examination of the system character of the PSM

${ }^{8}$ Komitet Obywatelski Mediów Publicznych. Retrieved September 29-30, 2016, from: http://www. polityka.pl/kultura/aktualnoscikulturalne/303377,1,komitet-obywatelski-mediow-publicznych.read. 
organization as such in the perspective presented here. The way of viewing the PSM organization from the ACI perspective as an independent, partially functional system is innovative. Because, in precisely the same way as civil society and the audience, the PSM organization is also denied its own independent, autonomous character.

According to all the advantages mentioned from the application of the participatory governance and the ACI approach, there is a need to apply them together with the PSM analysis model for respective PSM governance. A suitable media system for the initial application is the Polish public service media governance. The respective points in time for conducting the investigation were determined by milestones of the Broadcasting Act amendments or the attempts, usually after a change of government, to apply political influence (pressure) on broadcasting legislation. In this way, the change process of PSM regulation can be divided into several phases. As a result, various stages of differentiation processes which are connected to (media) transformation research can be identified and also, for example, the respective degree of politicization can be determined.

In the same way, phases of the increased commitment and involvement of civil society can be identified. In addition, with this method, it is possible to ascertain what level of importance is attributed to the PSM remit and to what degree other systemic orientations are represented. With the final results, it will become clear exactly which force at which point on the timeline had the most influence on PSM governance in Poland and what motivation lay behind this force.

Finally, especially with the aid of semi-structured interviews, it becomes possible to examine the question of whether civil society in Poland deserves the status of actor in the sense of actor-centered institutionalism, and what motivation is behind its public commitment. The assumption that Telewizja Polska may be regarded as an autonomous social organization with its own public values can influence the view of PSM in Poland by the actors involved and by society as a whole. This could help to strengthen PSM governance as well as its role in society.

\section{REFERENCES}

Arato, A. (1981). Civil Society Against the State: Poland 1980-81. Telos (47), pp. 23-47.

Bajomi-Lázár, P. (2015). Political Actors and the Colonization of the Media. In: Zielonka, J. (ed.), Media and politics in new democracies. Europe in a comparative perspective. Oxford: Oxford University Press.

Barber, B.R. (2004). Strong democracy: Participatory politics for a new age (20th anniversary ed. with a new preface). Berkeley: University of California Press.

Beisheim, M., Schuppert, G.F. (eds.) (2007). Staatszerfall und Governance. Baden-Baden: Nomos.

Bennett, J. (2014). Introduction: The Utopia of Independent Media: Independence, Working with Freedom and Working for Free. In: Bennett, J., Strange, N. (eds.), Routledge Research in Cultural and Media Studies. Media independence. Working with freedom or working for free? New York: Routledge.

Benz, A., Dose, N. (2010). Von der Governance-Analyse zur Policytheorie. In: Benz, A., Dose, N. (eds.), Lehrbuch: Vol. 1. Governance-Regieren in komplexen Regelsystemen. Eine Einführung (2nd ed.). Wiesbaden: VS Verlag für Sozialwissenschaften. 
Benz, A., Papadopoulos, Y. (eds.) (2006). Routledge/ECPR studies in European political science: Vol. 44. Governance and democracy: Comparing national, European and international experiences. London/New York: Routledge. Retrieved March 31, 2016 from http://www.loc.gov/catdir/enhancements/fy0653/2005017420-d.html.

Bevir, M. (2011). Governance as Theory, Practice, and Dilemma. In: Bevir, M. (ed.), The SAGE Handbook of Governance. Los Angeles, London, New Dehli, Singapore, Washington DC: SAGE.

Borowik, B. (2011). Obywatelska koncepcja mediów publicznych - perspektywa politologiczna [Social concept of public service media - political approach]. In: Bielawski, P., Ostrowski, A. (eds.), Media publiczne. System medialny w Polsce: pytania i dezyderaty [Public service media. Media system in Poland: questions and desiderata]. Poznań, Opole, Wrocław: Wydawnictwo Lena.

Carpentier, N. (2011). Media and participation: A site of ideological-democratic struggle. Bristol, Chicago: Intellect.

Carpentier, N. (2016). Beyond the Ladder of Participation: An Analytical Toolkit for the Critical Analysis of Participatory Media Processes. Javnost - The Public, 23(1), pp. 70-88.

Council of Europe (2009). Public service media governance: looking to the future: Discussion paper prepared by the Secretariat. Retrieved March 31, 2016 from http://www.coe.int/t/dghl/standardsetting/ media/doc/PSMgovernance_en.pdf.

Crouch, C. (2008). Post-democracy. Cambridge: Polity.

Dahl, R.A. (1989). Democracy and its critics. New Haven Conn: Yale University Press.

Dahlgren, P. (2003). Reconfiguring Civic Culture in the New Media Milieu. In: Corner, J., Pels, D. (eds.), Media and Political Style: Essays on Representation and Civic Culture. London: Sage.

Donges, P. (2002). Rundfunkpolitik zwischen Sollen, Wollen und Können: Eine theoretische und komparative Analyse der politischen Steuerung des Rundfunks. Wiesbaden: Westdeutscher Verlag.

Donges, P. (2003). Autonomie sichern, Offenheit erhöhen - Sicherung des Public Service. In: Donges, P., Puppis, M. (eds.), Die Zukunft des öffentlichen Rundfunks - internationale Beiträge aus Wissenschaft und Praxis. Köln: Herbert von Halem.

Donges, P. (2007). The New Institutionalism as a theoretical foundation of media governance. Communications, 32(3), pp. 325-330.

EBU (2014). Vision2020: An EBU Project Connecting to a networked society FULL REPORT. Retrieved March 31, 2016 from https://www.ebu.ch/files/live/sites/ebu/files/Publications/EBUVision2020-Full_report_EN.pdf.

EBU (2015). Legal Fokus: Governance Principles for PSM. Retrieved March 31, 2016 from from http:// www.ebu.ch/publications/principes-de-gouvernance-pour-le.

Eilders, C. (2011). Zivilgesellschaftliche Beteiligung im Medienbereich. In: Kleinsteuber, H.J., Nehls, S. (eds.), Media governance in Europa. Regulierung - Partizipation - Mitbestimmung. Wiesbaden: VS. Verlag für Sozialwissenschaften.

Fung, A., Wright, E.O. (2001). Deepening Democracy: Innovations in Empowered Participatory Governance. Politics \& Society, 29(1), pp. 5-41.

Galtung, J. (1999). State, Capital, and the Civil Society: The Problem of Communication. In: Vincent R., Nordenstreng K., Traber M. (eds.), Towards Equity in Global Communication: MacBride Update. Cresskill, NJ: Hampton Press, pp. 3-21.

Geissel, B. (2012). Impacts of democratic innovations in Europe: Findings and desiderata. In: Geissel B., Newton, K. (eds.), Evaluating Democratic Innovations. Curing the democratic malaise? London, New York: Routledge.

Głowacki, M. (2015). Governance of Public Service Media in Poland: The Role of the Public. Media and Communication, vol. 3, pp. 26-34.

Głowacki, M., Urbaniak, P. (2011). Poland: Between accontability and instrumentalization. In: Eberwein, T., et al. (eds.), Mapping media accountability — in Europe and beyond. Köln: Halem. 
Grote, J.R., Gbikpi, B. (eds.). (2002). Participatory governance: Political and societal implications; [Conference "Democratic and Participatory Governance: From citizens to Holders" held in Florence in September 2000]. Opladen: Leske + Budrich.

Hamelink, C.J., Nordenstreng, K. (2007). Towards Democratic Media Governance. In: de Bens, E. (ed.), Changing media - changing Europe: v. 4. Media between culture and commerce. Bristol, UK, Chicago, IL: Intellect Books.

Hess, A. (2015). The Polish think tank scene. In: Dobek-Ostrowska, B., Głowacki, M. (eds.), Democracy and media in Central and Eastern Europe 25 years on. Frankfurt am Main, New York: Peter Lang.

Jakubowicz, K. (1996). Civil Society and Public Sphere in Central and Eastern Europe: A Polish Case Study. Retrieved March 31, 2016 from http://www.nordicom.gu.se/sites/default/files/kapitelpdf/27_JAKUBO.pdf.

Jakubowicz, K. (2008). Participation and Partnership: a copernican revolution to reengineer Public Service Media for the 21st century: RIPE Keynote Presentation. Retrieved March 31, 2016 from http:// ripeat.org/library/Jakubowicz.pdf.

Jakubowicz, K. (2013). Media a demokracja w XXI wieku: Poszukiwania nowych modeli. Warszawa: Wydawnictwo Poltext.

Jarren, O., Donges, P. (2005). Der öffentliche Rundfunk in der Gesellschaft. Begründung, Wandel und Konflikte um eine Leitidee am Beispiel der Schweiz. In: Langenbucher, W.R., Ridder, C.M., Saxer, U., Steiniger, C. (eds.), Bausteine einer Theorie des öffentlich - rechtlichen Rundfunks. Festschrift für Marie-Luise Kiefer. Wiesbaden: VS Verlag für Sozialwissenschaften.

Jarren, O., Donges, P., Künzler, M. (2001). Der schweizerische öffentliche Rundfunk im Netzwerk: Möglichkeiten der Absicherung und Bindung der SRG an die Gesellschaft. Reihe Diskussionspunkt: Bd. 41. Zürich: IPMZ.

Karppinen, K., Moe, H. (2013). A critique of "media governance". Retrieved March 31, 2016 from http://blogs.helsinki.fi/kekarppi/files/2010/06/Karppinen-and-Moe2013.pdf.

Karppinen, K., Moe, H. (2016). What We Talk About When Talk About "Media Independence". Javnost - The Public, 23(2), pp. 105-119.

Klein, A., Rohde, M. (2003). Konturen der Zivilgesellschaft - Zur Profilierung eines Begriffs: Editorial zum Themenheft. Forschungsjournal Neue Soziale Bewegungen, 16(2), pp. 2-5.

Klimkiewicz, B. (2015). Between Autonomy and Dependency: Funding Mechanisms of Public Service Media in Selected European Countries. In: Arriaza Ibarra, K., Nowak, E., Kuhn, R. (eds.), Routledge studies in European communication research and education. Public service media in Europe. A comparative approach. London, New York: Routledge.

Kooiman, J.P. (2003). Governing as governance. London: SAGE.

Lowe, G.F. (ed.) (2010). The public in public service media: RIPE 2009. Göteborg: Nordicom.

Luthard, W. (1999). Politische Steuerung und akteurzentrierter Institutionalismus. Swiss Political Science Review, 5(2), pp. 155-166.

Mayntz, R. (1988). Funktionelle Teilsysteme in der Theorie sozialer Differenzierung. In: Mayntz R., Rosewitz, B. (eds.), Schriften des Max-Planck-Instituts für Gesellschaftsforschung, Köln: Bd. 1. Differenzierung und Verselbständigung. Zur Entwicklung gesellschaftlicher Teilsysteme. Frankfurt am Main, New York: Campus.

Mayntz, R. (2004). Governance Theory als fortentwickelte Steuerungstheorie?: MPIfG Working Paper 04/1. Retrieved March 31, 2016 from https://www.econstor.eu/handle/10419/44296.

Mayntz, R. (2009). Governancetheorie: Erkenntnisinteresse und offene Fragen. In: Grande, E., May, S. (eds.), Schriften des Münchner Centrums für Governance-Forschung: Vol. 1. Perspektiven der Governance-Forschung. Baden-Baden: Nomos.

McLaverty, P. (2011). Participation. In: Bevir, M. (ed.), The SAGE Handbook of Governance. Los Angeles, London, New Delhi, Singapore, Washington DC: Sage.

McQuail, D. (1992). Media Performance: Mass Communication and the Public Interest. London, Thousand Oaks, New Delhi: SAGE. 
Media and Information Society Division Directorate General of Human Rights and Legal Affairs Council of Europe (2009). Public service media governance: Looking to the future: Discussion paper prepared by the Secretariat. Retrieved March 31, 2016 from https://www.coe.int/t/dghl/ standardsetting/media/doc/PSMgovernance_en.pdf.

Michnik, A. (1985). Letters from prison and other essays. Studies in Societies and culture in East Central Europe: Vol. 2. Berkeley, California: University of California Press. Retrieved March 28, 2016 from http://www.loc.gov/catdir/enhancements/fy1603/85001196-b.html.

Newman, S. (2000). Globalization and Democracy. In: Greven, M.T., Pauli, L.W. (eds.), Democracy beyond the state? The European Dilemma and the emerging Global Order. Lanham, Boulder, New York, Oxford: Rowman \& Littlefield Publishers.

Norris, P. (2012). Making democratic governance work: How regimes shape prosperity, welfare, and peace. Cambridge: Cambridge University Press.

Offe, C. (2009). Governance: An "Empty Signifier"? Constellations, 16(4), pp. 550-562.

Pateman, C. (1970). Participation and democratic theory. Cambridge: Cambridge University Press.

Puppis, M. (2007). Media Governance as a horizontal extension of Media Regulation: The importance of Self- and Co-Regulation. Communications, 32(3), pp. 330-336.

Puppis, M. (2010a). Einführung in die Medienpolitik (2., überarb. Aufl.). UTB: 2881: Medien- und Kommunikationswissenschaft, Politikwissenschaft. Konstanz: UVK-Verl.-Ges.

Puppis, M. (2010b). Media Governance: A New Concept for the Analysis of Media Policy and Regulation. Communication, Culture \& Critique, 3(2), pp. 134-149.

Rhodes, R.A.W. (1996). The New Governance: Governing without Government. Political Studies, 44(4), pp. 652-667.

Schimank, U. (2007). Theorien gesellschaftlicher Differenzierung. Wiesbaden: VS Verlag für Sozialwissenschaften.

Scott, W.R. (2001). Institutions and organizations. Foundations for organizational science. Thousand Oaks, California: SAGE.

Smolar, A. (1996). From Opposition to Atomization. Journal of Democracy, 7(1), pp. 24-38.

Søndergaard, H. (1999). Some Reflections on Public Service Broadcasting. Nordicom Review, 20(1), pp. 21-28.

Stępka, P. (2010). Public Service Broadcasting in Poland: Between Politics and Market. In: Iosifidis, P. (ed.), Reinventing Public Service Communication. London: Palgrave Macmillan UK.

Syvertsen, T. (1999). The many uses of the "public service" concept. Nordicom Review, 20(1), pp. 5-12.

Syvertsen, T. (2004). Citizens, Audiences, Customers and Players: A Conceptual Discussion of the Relationship Between Broadcasters and Their Publics. European Journal of Cultural Studies, 7(3), pp. 363-380.

Voltmer, K. (2000). Massenmedien und demokratische Transformation in Osteuropa. Strukturen und Dynamik öffentlicher Kommunikation im Prozeß des Regimewechsels. In: Klingemann, H.D., Neidhardt, F., (eds.), Zur Zukunft der Demokratie. Herausforderungen im Zeitalter der Globalisierung. Berlin: Edition Sigma.

Wagner, M., Berg, A.C. (2015). EBU Legal Focus: Governance Principles for Public Service Media. Retrieved March 28, 2016 from http://www.ebu.ch/publications/principes-de-gouvernance-pour-le.

Walk, H. (2011). Partizipative Governance. Beteiligungsformen in der Klimapolitik. In: Demirović, A., Walk, H. (eds.), Demokratie und Governance. Kritische Perspektiven auf neue Formen politischer Herrschaft. Münster: Westfälisches Dampfboot.

Załęski, P.S. (2012). Neoliberalizm i społeczeństwo obywatelskie. Monografie Fundacji na rzecz Nauki Polskiej. Toruń: Wydawnictwo Naukowe Uniwersytetu Mikołaja Kopernika.

Zimmer, A. (2012). Die verschiedenen Dimensionen der Zivilgesellschaft. Retrieved March 28, 2016 from http://www.bpb.de/politik/grundfragen/deutsche-verhaeltnisse-eine-sozialkunde/138713/ dimensionen. 